\title{
The Balinese Traditional Law Instrument: a Realism between the Balance of Cosmic and Human Rights Context
}

\author{
I Gede Yusa*, Ni Ketut Supasti Dharmawan ${ }^{* *}$ \\ DOI: https://doi.org/10.22304/pjih.v5n3.a3
}

Submitted: October 21, 2018 | Accepted: December 23, 2018

\begin{abstract}
This study aims to examine whether the substance of Balinese traditional law instrument (the awig-awig) contradicts to human rights. This study employed normative legal research. The result shows that the awig-awig stands as convention but, on the other side, it is constructed by the Desa Pakraman under the Balinese Local Government Regulation Number 3 of 2003. Therefore, based on the hierarchy of the norm, it is not a fully autonomous community. Moreover, it is separated from the Unitary State of the Republic of Indonesia and internationally. The traditional law instrument should inline to the national law and international law, especially those related to human rights values. Although it aims to keep the balance of cosmic or universe, international and national instruments related to human rights should be used as a reference to construct customary rules, particularly for the one that is related to kesepekang (a rejection) and manak salah (a sanction for boy and girl born twin). It potentially causes social friction due to its disruption to the human rights values and adequate standard of living.
\end{abstract}

Keywords: balance cosmic, Balinese traditional law instrument, human rights.

\section{Instrumen Hukum Tradisional Bali: Realisme antara Keseimbangan Kosmik dan Hak Asasi Manusia}

\begin{abstract}
Abstrak
Tujuan dari studi ini adalah untuk mengkaji apakah substansi instrumen hukum tradisional Bali yang juga disebut Awig-Awig bertentangan dengan hukum hak asasi manusia. Studi ini menggunakan penelitian hukum normatif. Hasil penelitian menunjukkan bahwa Awig-awig sebagai instrumen hukum tradisional di satu sisi bentuknya sebagai hukum tidak tertulis, tetapi di sisi lain dikonstruksi oleh Desa Pakraman berdasarkan Peraturan Pemerintah Daerah Bali Nomor 3 tahun 2003, oleh karena itu dari hirarki norma, Desa Pakraman bukan komunitas yang sepenuhnya otonom dalam membuat ketentuan, apalagi terpisah dari Negara Kesatuan Republik Indonesia dan internasional. Instrumen hukum tradisional harus sejalan dengan Hukum nasional dan hukum internasional, terutama yang terkait dengan nilai-nilai hak asasi manusia. Meskipun sifatnya bertujuan untuk menjaga keseimbangan kosmik atau alam semesta, nampaknya instrumen-instrumen internasional dan nasional
\end{abstract}

PADJADJARAN Journal of Law Volume 5 Number 3 Year 2018 [ISSN 2460-1543] [e-ISSN 2442-9325]

\footnotetext{
Lecturer of the Department of Constitutional Law, Udayana University, Jalan Bali No. 1 Sanglah Denpasar, gedeyusa@rocketmail.com, S.H. (Universitas Udayana), M.H. (Universitas Airlangga), Dr. (Universitas Brawijaya).

** Lecturer of the Department of Private Law, Udayana University, Bali, Jalan Bali No. 1 Sanglah Denpasar, arasswk@yahoo.com, S.H. (Universitas Udayana), M. Hum. (Unversitas Diponegoro), LL.M. (Maastricht University), Dr. (Universitas Diponegoro).
} 
yang terkait dengan hak asasi manusia perlu digunakan sebagai referensi oleh Desa Pakraman dalam membangun aturan-aturan adat, terutama yang berkaitan dengan kesepekang (penolakan dari Desa Pakraman) dan manak salah (terkait dengan sanksi bagi anak kembar laki-laki dan perempuan yang dilahirkan sebagai kembar sekaligus) yang berpotensi menyebabkan gesekan sosial karena gangguannya terhadap nilai-nilai hak asasi manusia dan standar kehidupan yang layak.

Kata kunci: hak asasi manusia, instrumen hukum tradisional Bali, keseimbangan kosmik.

\section{A. Introduction}

As a movement, human rights have emerged several centuries ago. For instance, it was resulted from several revolutions like the American and the French Revolutions in the Middle Ages and especially after the two world wars. The development of international human rights protection can be understood. The competent bodies of the United Nations (UN) have become the pioneer of Human Rights respect, promotion, and protection in the world both through the Universal Declaration of Human Rights 1948 and two main International Covenants are Covenant on Civil and Political Rights 1966 and Covenant on Economic, Social and Cultural Rights 1966 that so-called International Bill of Human Rights. ${ }^{1}$ In national context, Indonesia has ratified the ICCPR 1966 and ICESCR $1966 .{ }^{2}$ In addition, Indonesia has also adopted the human rights basic principles as stated both in the UDHR 1948 and in the aboveexplained main human rights covenants. Such absorptions can be seen in a number of national laws and regulations, including the most important legal instruments: the 1945 Constitution of the Republic of Indonesia (the after amendments version hereinafter referred to as the 1945 Constitution) $^{3}$ and the Law Number 39 of 1999 on Human Rights (hereinafter referred to as the Indonesian Human Rights Law) ${ }^{4}$. Up to 2004, the Indonesian Government has already ratified several conventions. They cover the Conventions on Elimination of All Forms of Racial Discrimination, Elimination of all Forms of Discrimination against Women, and the Rights of the Child. Along with the development of international human rights instruments, Indonesia has also ratified the Convention on the Rights of Persons with Disabilities. ${ }^{5}$ That commitment is intertwined with Indonesia's obligation to respect,

1 Christian Tomuschat, Human Rights between Idealism and Realism, $2^{\text {nd }}$ Edition, New York: Oxford University Press, 2008, p. 29.

2 Indonesia has ratified the ICCPR 1966 and ICESCR 1966 by the Law Number 11 of 2005 and the Law Number 12 of 2005 .

3 Chapter X A on Human Rights from Article 28 A to Article $28 \mathrm{~J}$ of the 1945 Constitution. See further in Jimly Asshidiqie, Komentar atas Pasal-pasal Undang-undang Dasar Negara Republik Indonesia Tahun 1945, Jakarta: Sinar Grafika, 2010, pp. 123-137.

4 The General Elucidation states that," ... in this Law, the regulation on human rights is based on the UN Human Rights Declaration, UN Convention on Elimination of All Forms of Discriminations Against Women, UN Convention on th Rights of the Child and other international instruments which govern human rights. The content of this Law is also adjusted to the legal needs of the community and the development of national law based on Pancasila and the 1945 Constitution...". See General Elucidation of Law Number 39 of 1999 on Human Rights [Penjelasan Umum atas Undang-Undang Nomor 39 Tahun 1999 tentang Hak Asasi Manusia].

5 See General Elucidation of Law Number 19 of 2011 on the Ratification of Convention on the Rights of Persons with Disabilities [Penjelasan Umum atas Undang-Undang Nomor 19 Tahun 2011 tentang Pengesahan Konvensi Mengenai Hak-Hak Penyandang Disabilitas]. 
to promote, and to protect human rights. It can be seen in Indonesia's written laws, for instance the Laws that are ratifications of the International Human Rights Conventions as well as national Laws that adopt international Human Rights instruments.

In the local context, specifically in Bali, the issues of human rights can be seen in the awig-awig of Desa Pakraman (Balinese Traditional Law Instruments constructed by Desa Pakraman). The Desa Pakraman is regulated under the Bali Local Regulation Number 3 of 2001 that has been amended by the Bali Local Regulation Number 3 of 2003. The duty of Desa Pakraman under Article 5 is constructing Awig-Awig, managing the village, managing the village's property, and, together with the government, completing development in various sectors of religion, culture, society, developing Balinese cultures in order to enrich, to preserve, and to develop national culture in general and local culture in particular based on discussion and consensus. ${ }^{6}$ The awig-awig is Balinese Customary Instruments that belongs to Autonome Verordnungen (autonomy implementation regulation, which is categorized as unwritten law). Under the "Murdacita" (Opening) concept or the "Patitis lan Pamikukuh" (Direction and Foundation) section, the awig-awig states, "Pancasila, the Constitution, and the Laws shall be prioritized". Therefore, the contents or the substances of awig-awig should be in line to the mentioned instruments. However, in practice, several occurred cases in Desa Pakraman are closely related to human rights violation, such as the case of Manak Salah in 2004 (sanction for twin -boy and girl- in one pregnancy) ${ }^{7}$, Kesepekang Case in 2012 (Rejection of Desa Pakraman to the change of someone's name from non-Gusti into Gusti) ${ }^{8}$, the case of expulsion from Desa Pakraman in 2015 due to black magic (leak) accusation. ${ }^{9}$ The cases indicates that there are human rights violations in Desa Pakraman. Based on the phenomena, it is important to study whether those examples of cases represent the substance of the Awig-Awig. It further questions whether the substance of awigawig is in line with human rights laws.

Philips emphasizes that our concern on human rights will encounter conflicts on human rights (for example the right to security and to privacy or between the right to freedom of expression and to freedom of religion). ${ }^{10}$ Furthermore, Simmons reveals that the International Bill of Rights has the power to the direction of political dimension but it cannot transform into civil liberties magically. ${ }^{11}$

This study aims to assess the substance of awig-awig based on human rights instruments. The hierarchy of Stufenbau, in association with human rights

6 Arjawa, I. B. S., \& Jayantiari, I. M. R., "Democratic values in Balinese traditional society: Analysis of the making and the content of Desa Pakraman's awig-awig", Masyarakat, Kebudayaan dan Politik, Vol. 30, No. 4, 2017, p. 431.

7 The cases occurred in Padangbulia, the Regency of Buleleng Bali, see Bali Post Daily Newspaper, October 4, 2004.

8 The rejection case happened in Dawan Village, the regency of Klungkung Bali, see Den Post Daily Newspaper, January 8, 2012.

9 The case occurred in Lendih Village the Regency of Bangli Bali, see Den Post Daily Newspaper, October 1, 2015.

10 J. Philips, "On setting priorities among human rights", Human Rights Review, Vol. 15, No. 3, 2014, p. 256.

11 B. Simmons, "Civil Rights in International Law: Compliance with Aspects of the "International Bill of Rights", Indiana Journal of Global Legal Studies, Vol. 16, No. 2, 2009, p. 437. 
instrument, plays important role in addressing human rights issues to understand the implementation of awig-awig since it serves as a practical rule for the community. By examining the form of awig-awig as unwritten Law that exists as a part of Balinese Local Regulation. In other words, the awig-awig should not contrary to National Laws. Furthermore, by understanding the balance concept of cosmic based on the Principle of Tri Hita Karana, it can be possible to generate some lessons. Gradually, Indonesia increases its international relations. Thus, in local context, Bali needs to suit their local regulation to improve the balance cosmic and human rights instruments.

This study first elaborates international and national human rights instruments. Then, it examines the awig-awig that is contrary to human rights laws and shows lessons from different perspective, namely the value of balance Tri Hita Karana. Eventually, this paper elaborates the ways to synergize both the local context of awig-awig and human rights dimensions.

\section{B. Human Rights Context and Standards of Living and Health Care}

The development of human rights has been passed a long history. At the beginning of its development, some scholars argue that the ideas of human rights are developed from modern western societies. The others argue that human rights are considered universal. The essence of human rights is to protect dignity. The idea of dignity is universal and cannot come from internationalization. The idea of human rights does not originate from any particular world, such as western. ${ }^{12}$ However, the emerging of international human rights can be considered since the UN has adopted two main human rights instruments in the form of Covenants: the International Covenant on Civil and Political Rights 1966 (ICCPR 1966) and the International Covenant on Economic, Social, and Cultural Rights 1966 (ICESCR 1966). The two covenants contain further detailed descriptions of the UDHR 1948. Those covenants have legally binding power once they are ratified by the UN-member states. ${ }^{13}$ As a legal instrument, the two covenants have necessary human rights universal legal values and norms of living together. ${ }^{14}$ Human rights are a birthright of all human being. The Article 1 of the UDHR provides that all human beings are born free and equal in dignity and rights. ${ }^{15}$ In this contexts, human rights is fundamental to humankind itself including the living standard of every human beings. The Article 5 of the UDHR clearly regulates that no one shall be subjected to torture or to cruel and inhumane or degrading treatment or punishment. Furthermore, the Article 25(1) emphasizes adequate housing, health, food, clothing, including medical care for everyone. Particularly, in Article 25(2), the protection of vulnerable motherhood and childhood can be understood as the right to special care and assistance. The

12 Michelo Hansungule, The Historical Development of International Human in Chowdhury (et.al.), An Introduction to International Human Rights Law, Leiden: Koninklijke Brill, 2010, p. 28.

13 Boer Mauna, Hukum Internasional, Pengertian, Peranan dan Fungsi dalam Era Dinamika Global, $2^{\text {nd }}$ Edition, Bandung: Alumni, 2011, pp. 685-690.

14 T. Meyer in Romli Atmasasmita, Reformasi Hukum, Hak Asasi Manusia, dan Penegakan Hukum, Bandung: Mandar Maju, 2001, pp. 165-166.

15 D. Kuwali, "Battle for Sex: Protecting Sexual (ity) Rights in Africa", Human Rights Quarterly, Vol. 36, 2014, p. 30. 
ICESCR also emphasizes protection for mothers during pregnancy and after childbirth in Article 10(1). It means that both mother and baby are entitled to get well-being living standard for housing and health care. As part of the Bill of Rights, the ICCPR, in Article 24(1), provides protection against discrimination to children, ${ }^{16}$ whatever the condition of the newborn child (healthy, twins, etc) is. This provision could be relevant to protect children to entitled their rights of protection for a decent living standard, including housing, food, and healthcare. This covenant also obligates states to respect the rights of individuals to freedom of thought, to believe, and to practice religion in Article 18, as well the right to freedom of expression in Article 19(2) of ICCPR.

Other than the UDHR and the two main covenants, the UN has also adopted several human rights conventions that also contains several norms to protect human beings in accordance with the living standard. The instruments are as follows; the Convention on Political Rights of Women (1952), the Convention on Nationality of Married Woman (1957), the Convention on Racial Discrimination (1965), the Non-Applicability of Statutory Limitations to War Crimes and Crimes against Humanity (1968), the Convention on Elimination of all Forms of Discrimination Against Women (1979), The Convention against Torture and Other Cruel, Inhuman or Degrading Treatment or Punishment (1984), The Convention against Apartheid in Sports (1984), as well as Convention on Rights of the Child (1989). As mentioned previously, Indonesia has already become members of several International Human Rights conventions. Moreover, Indonesia has ratified and adopted the conventions into national law, e.g. the Indonesian Human Rights Law.

In relation to the validity of norm theory or Stufenbau theory (Stufenbau des Rechtsordnung), ${ }^{17}$ in Indonesian contexts, all rules on Human Rights that are lower than the 1945 Constitution do not have legal validity if the rules are in conflict with the human rights provisions stipulated in the Constitution. Furthermore, if there is a provision in lower hierarchy, whether in the contexts of Government and Regional Regulations (Local Government Regulation) that are contrary to the Law Number 39 of 1999 on Human Rights, the rule also has no validity.

In Bali, the term of desa (literally means village) refers to two meanings: Desa Dinas, a village is a unit of Government administration territory, and Desa Pakraman, a territory of the indigenous Balinese. ${ }^{18}$ Desa Pakraman in Bali has its own Balinese adat (customary) law instrument, called awig-awig. As a customary product of autonomous region, awig-awig is in the level of "Autonome Satzungen" of the Stufenbau des Recht theory, which is the lowest level. Sequentially, from the highest to the lowest levels, the theory covers Grundgesetz (Constitution), Formelle Gesetz (Laws), and Autonome Verordnungen (Regulations of Autonomy, including

16 Article 24 (1) of ICCPR regulates that every child shall have, without any discrimination of race, colour, sex, language, religion, national or social origin, property or birth, the rights to such measures of protection as are required by his status as a minor, on the part of his family, society and the state, see Sandy Ghandhi, Blackstone's International Human Rights Documents, ${ }^{\text {th }}$ Edition, New York: Oxford University Press, 2008, p.45. Hans Kelsen, General Theory of Norm, Oxford: Clarendon Press, 1991, p. 46.

18 M.S.P.D. Salain, D. Isles, and I.G.N. Wairocana, "Regulating Indigenous Culture as a Tourism Economic Resource", Udayana Journal of Law and Culture, Vol. 1, No. 2, 2017, pp. 122-123. 
the customs). ${ }^{19}$ Therefore, if it turns out that the provisions of the awig-awig of Desa Pakraman are contrary to the higher human rights laws and regulations, the provisions of the awig-awig will become invalid. This kind of conclusion seems to be in line with the perception of Desa Pakraman itself. It is because in the Murdacita (Preamble or Opening) section or in the Patitis lan Pamikukuh section (Direction and Foundation) of awig-awig states that "Pancasila, the 1945 Constitution, and the Laws shall be prioritized". Therefore, an awig-Awig should be in line with the mentioned instruments.

\section{The Balinese Traditional Law Instrument (Awig-Awig) in the Context of Balance Cosmic.}

The awig-awig regulates the relationship amongst human being, between human and environment, and between human and the Gods. It maintains order within community and preserve safety and security for the social life of the community. Every Desa Pakraman has its own adat law, which is influenced by particular condition, namely space (desa), time (kala), and situation (patra). However, awigawig also has common elements Catur Dresta, the concepts of four basic elements of rule. It consists of old tradition (Pura dresta), religion rules (sastra dresta), general public rules and opinion (loka dresta), and local public opinion (desa dresta). The unique structure of awig-awig makes it flexible, dynamic, and responsive to world development. ${ }^{20}$ Sudantra reveals that awig-awig is a legal product of a traditional organization, which is generally made in consensus by its members, and act as a guideline for the conduct of the members. ${ }^{21}$ Awig-awig is based on the philosophy of Tri Hita Karana originating from Hindu teachings. Textually, it means three causes of welfare (tri $=$ three, hita $=$ welfare, karana $=$ cause). These three elements are Sanghyang Jagatkarana (the Creator), Bhuana (universe), and manusa (human). The welfare of human being in this world can be realized only if there is a balance of relations between those three elements. ${ }^{22}$

Concerning cosmic balance, traditional Balinese, when they face disorder, they usually do purification ceremony to return and to keep the cosmic balance. For instance, when the Bali bombing tragedy happened, the traditional Balinese implemented special Hindu ceremony Pemarisuda Karipubaya to purify the universe after the tragedy. The universe was believed to be polluted. It disrupted the balance of Bhuwana Agung (Macrocosm) and Bhuwana Alit (Microcosm) of Bali. It is expected to be purified through the spiritual approach, which symbolically contains a message of peace, unity, and tolerance to penetrate the boundaries of race, state,

19 Maria Farida Indrati Soeprapto, Ilmu Perundang-undangan 1, Jenis, Fungsi dan Materi Muatan, Yogyakarta: Kanisius, 2007, pp. 58-66, see also Jimly Asshidiqie, Perihal Undang-undang, Jakarta: Konstitusi Press, 2016, p. 72, pp. 31-120.

20 H.C. Ndun, S. Suttor, and I.G.A.A.D. Widhiyaastuti, "Does Customary Law Discriminate Balinese Women's Inheritance Rights?", Udayana Journal of Law and Culture, Vol. 2, No. 1, 2018, p. 105.

21 I.K. Sudantra, "Pengaturan Penduduk Pendatang dalam Awig-Awig Desa Pakraman" PIRAMIDA, 2000, p. 3.

22 Ibid, pp. 5-6. 
ethnicity, as well as religion. ${ }^{23}$ It can be considered that Balinese people with their local wisdom conduct particular purification ceremony to maintain cosmic balance. In legal context, the existence of awig-awig as the manifestation of local wisdom Tri Hita Karana is regulated in Article 1(11) of the Balinese Local Government Regulation Number 3 of 2001. Furthermore, the existence of awig-awig can be seen under Article $18 \mathrm{~B}(2)$ of the 1945 Constitution. The article recognizes and respects the units of customary law of indigenous community along with their traditional rights as long as it is in accordance with the development of people and the principle of the Unitary State of the Republic of Indonesia. Desa Pakraman is an indigenous community in Bali based on Article 1(4) of Balinese Local Government Regulation Number 3 of 2001 on Desa Pakraman that has been amended by Balinese Local Government Regulation Number 3 of 2003. It mentions "Desa Pakraman is a customary law community unit in the Province of Bali, which has a unity of tradition and manners of Hindu community life for generations in the ties of kahyangan tiga or kahyangan desa. It has a certain area and own property and the right to take care of their own household".

Although awig-awig in nature is a manifestation of Tri Hita Karana to keep the cosmic balance or to preserve safety and security of the community, this rule, partially, is considered contradict to human rights laws. Some scholars argue that the traditional instrument discriminates the inheritance rights of women. Westendorp, in her study, assesses how Balinese women are discriminated against their inheritance rights based on religious and traditional laws. ${ }^{24}$ The inheritance rights of women from generation to generation and for centuries have been discriminated by the patrilineal system in Balinese Customary Law. A decision of Majelis Utama Desa Pakraman (the Main Assembly of the Desa Pakraman) states that a woman is considered has the right to inherit $1 / 3$ of property as long as the woman do not convert from her religion. ${ }^{25}$

Based on several cases, it seems that the rules do not only discriminate women, but also other vulnerable groups. Several cases are related to human rights violations, e.g. mass anger or acts of suppression by majority against minority groups or against an individual (a member of Desa Pakraman). The cases can be seen in the table below.

23 W.G. Suacana, "Budaya demokrasi dalam kehidupan masyarakat desa di Bali", Journal of Bali Studies, Vol. 1, No. 1, 2011, p. 89.

24 I. Westendorp, "Personal Status Law and Women's Right to Equality in Law and in Practice: The Case of Land Rights of Balinese Hindu Women", Journal of Human Rights Practice, Vol. 7, No. 3, 2015, p. 433.

25 N.K. Setyawati, "Kedudukan perempuan Hindu menurut hukum waris adat Bali dalam perspektif kesetaraan gender", Jurnal Penelitian Agama Hindu, Vol. 1, No. 2, 2017, p. 624. 
Table 1. Customary Cases Related to the Human Rights Violations in Several Desa Pakraman during 2000- 2015 26

\begin{tabular}{|c|c|c|c|c|}
\hline No & Date & Cases Occured & Main Cases & Victims \\
\hline (1) & $(2)$ & (3) & (4) & (5) \\
\hline 1. & $\begin{array}{ll}17 & \text { August } \\
2000 & \end{array}$ & $\begin{array}{l}\text { Klusu, } \quad \text { Pejeng, } \\
\text { Gianyar } \\
\text { anger) }\end{array}$ & $\begin{array}{l}\text { Dispute on } \\
\text { Kahyangan Tiga } \\
\text { and the Setra } \\
\text { (cemetery) land }\end{array}$ & $\begin{array}{l}12 \text { houses, } 1 \text { car } \\
\text { and } 1 \text { motorcycle } \\
\text { were destroyed. }\end{array}$ \\
\hline 2. & $\begin{array}{ll}1 & \text { January } \\
2001 & \end{array}$ & $\begin{array}{l}\text { Sengguan, } \\
\text { Penarungan, } \\
\text { Mengwi, } \\
\text { Badung (mass } \\
\text { anger) }\end{array}$ & $\begin{array}{l}\text { For not becoming } \\
\text { member of banjar } \\
\text { (a traditional } \\
\text { organization as a } \\
\text { part of Desa } \\
\text { Pakraman) for } 8 \\
\text { years }\end{array}$ & $\begin{array}{lr}\text { The house of the } \\
\text { person } \\
\text { concerned } \\
\text { destroyed. }\end{array}$ \\
\hline 3. & $\begin{array}{ll}26 & \text { March } \\
2001 & \end{array}$ & $\begin{array}{l}\text { Banjar Pasekan, } \\
\text { Kediri, Tabanan } \\
\text { (mass anger) }\end{array}$ & $\begin{array}{l}\text { Someone's act was } \\
\text { considered as } \\
\text { disgrace the Desa } \\
\text { Pakraman's temple }\end{array}$ & $\begin{array}{lr}\text { The house of the } \\
\text { person } \\
\text { concerned } \\
\text { destroyed. }\end{array}$ \\
\hline 4. & $\begin{array}{ll}2 & \text { August } \\
2001 & \end{array}$ & $\begin{array}{l}\text { Nyuh Tebel, } \\
\text { Manggis, } \\
\text { Karangasem } \\
\text { (mass anger) }\end{array}$ & $\begin{array}{l}\text { Member of Nyuh } \\
\text { Tebel felt offended } \\
\text { against member of } \\
\text { Pasedahan }\end{array}$ & $\begin{array}{l}3 \text { small shops were } \\
\text { destroyed, } \\
\text { houses } \\
\text { burned down. }\end{array}$ \\
\hline 5. & $\begin{array}{l}7 \quad \text { January } \\
2002\end{array}$ & $\begin{array}{l}\text { Yang Api, Abian } \\
\text { Tuwung, } \\
\text { Tabanan (mass } \\
\text { anger) }\end{array}$ & $\begin{array}{l}\text { Dispute on Pelaba } \\
\text { Pura (the property } \\
\text { belonging Temple) } \\
\text { between Desa } \\
\text { Pakraman and } \\
\text { member (krama) of } \\
\text { village group }\end{array}$ & $\begin{array}{l}43 \text { houses were } \\
\text { burned down, } \\
\text { some worship } \\
\text { places (pelinggih) } \\
\text { in Dalem temple } \\
\text { were destructed. }\end{array}$ \\
\hline 6. & 6 April 2002 & $\begin{array}{l}\text { Kapal, Badung } \\
\text { (mass anger) }\end{array}$ & $\begin{array}{l}\text { Temple widening } \\
\text { by taking the yard } \\
\text { owned by } \\
\text { Pemangku (the one } \\
\text { who led the } \\
\text { worship in the } \\
\text { temple) }\end{array}$ & $\begin{array}{l}\text { Pemangku's house } \\
\text { was destructed. }\end{array}$ \\
\hline
\end{tabular}

26 The sources of data: (1) Bali Post Daily Newspaper dated 19 September 2002 (case No. 1 to No. 11); (2) Bali Post Daily Newspaper dated 4 October 2004 (Case No. 12 to No. 13); and (3) daily newspaper of DenPost (Case No. 14 and No. 15). 


\begin{tabular}{|c|c|c|c|c|}
\hline 7. & $\begin{array}{l}13 \text { February } \\
2002\end{array}$ & $\begin{array}{l}\text { Katung, } \\
\text { Kintamani, } \\
\text { Bangli (mass } \\
\text { anger) }\end{array}$ & $\begin{array}{l}\text { Dispute on ayahan } \\
\text { desa } \\
\text { (Obligation for } \\
\text { Desa Pakraman) }\end{array}$ & $\begin{array}{l}13 \text { houses were } \\
\text { burned down, } 2 \\
\text { motor cycles and } 2 \\
\text { cars were } \\
\text { destructed. }\end{array}$ \\
\hline 8. & 25 April 2002 & $\begin{array}{l}\text { Banjar Lebah, } \\
\text { Susut, Bangli } \\
\text { (Rejection from } \\
\text { Desa Pakraman) }\end{array}$ & $\begin{array}{l}\text { Someone was not } \\
\text { registered as a } \\
\text { member of the } \\
\text { banjar }\end{array}$ & $\begin{array}{l}\text { Ni Nengah Prapti's } \\
\text { corpse could not } \\
\text { be buried and } \\
\text { cannot pass other } \\
\text { Desa Pakraman. }\end{array}$ \\
\hline 9. & 4 June 2002 & $\begin{array}{l}\text { Culik, Abang, } \\
\text { Karangasem } \\
\text { (mass anger) }\end{array}$ & $\begin{array}{l}\text { Opposition to the } \\
\text { plan to establish a } \\
\text { new Desa } \\
\text { Pakraman by the } \\
\text { old Desa Pakraman }\end{array}$ & $\begin{array}{l}1 \text { person died, } 30 \\
\text { houses and small } \\
\text { shops were burned } \\
\text { down, } 2 \text { motor } \\
\text { cycles were burned } \\
\text { down. }\end{array}$ \\
\hline 10. & $\begin{array}{ll}25 & \text { August } \\
2002 & \end{array}$ & $\begin{array}{l}\text { Sengguan, } \\
\text { Penarungan, } \\
\text { Badung (mass } \\
\text { anger) }\end{array}$ & $\begin{array}{l}\text { Old case. Netra was } \\
\text { not performed the } \\
\text { obligation under } \\
\text { Desa Pakraman } \\
\text { upon the } \\
\text { customary land } \\
\text { that he used. }\end{array}$ & $\begin{array}{l}\text { Netra's house was } \\
\text { burned down and } \\
\text { the ruins of his old } \\
\text { house were } \\
\text { leveled. }\end{array}$ \\
\hline
\end{tabular}




\begin{tabular}{|c|c|c|c|c|}
\hline 11. & $\begin{array}{l}8 \text { September } \\
2002\end{array}$ & $\begin{array}{l}\text { Kerta, } \\
\text { Payangan, } \\
\text { Gianyar } \\
\text { (Arbitrary } \\
\text { actions of Desa } \\
\text { Pakraman) }\end{array}$ & $\begin{array}{l}\text { According to the } \\
\text { "Bawos" or } \\
\text { spiritual guidance } \\
\text { delivered by Jero } \\
\text { Tapakan, Barwana } \\
\text { (the former } \\
\text { Bendesa) has } \\
\text { stolen daksina (a } \\
\text { type of offerings) }\end{array}$ & $\begin{array}{l}\text { Bawarna was tied } \\
\text { up in the cemetery } \\
\text { at } 00.00 \text { am and his } \\
\text { three partners } \\
\text { were received } \\
\text { customary sanction } \\
\text { in the form of } \\
\text { ostracized from the } \\
\text { Desa Pakraman } \\
\text { (kasepekang) } \\
\text { because they were } \\
\text { accused of using } \\
\text { black magic } \\
\text { (ngeleyak). }\end{array}$ \\
\hline 12. & $\begin{array}{ll}18 & \text { March } \\
2004 & \end{array}$ & $\begin{array}{l}\text { Padangbulia, } \\
\text { Buleleng } \\
\text { (Customary } \\
\text { Sanction) }\end{array}$ & $\begin{array}{l}\text { Manak salah (give } \\
\text { birth to twin - boy } \\
\text { and girl at once in } \\
\text { one pregnancy) }\end{array}$ & $\begin{array}{l}\text { The twin (the boy } \\
\text { and girl born as } \\
\text { twin at once or } \\
\text { anak kembar } \\
\text { buncing) } \\
\text { exiled for } \\
\text { months. }\end{array}$ \\
\hline 13. & $\begin{array}{l}3 \text { October } \\
2004\end{array}$ & $\begin{array}{l}\text { Bungaya, } \\
\text { Karangasem } \\
\text { (Rejection from } \\
\text { Desa Pakraman) }\end{array}$ & $\begin{array}{l}\text { A group of Desa } \\
\text { Pakraman } \\
\text { members used } \\
\text { Gusti title name }\end{array}$ & $\begin{array}{l}\text { Threat of expulsion } \\
\text { from the area of } \\
\text { Desa Pakraman. }\end{array}$ \\
\hline
\end{tabular}




\begin{tabular}{|c|c|c|c|c|}
\hline 14. & $\begin{array}{l}8 \quad \text { January } \\
2012\end{array}$ & $\begin{array}{l}\text { Dawan, } \\
\text { Klungkung } \\
\text { (Rejection from } \\
\text { Desa Pakraman } \\
\text { due to change } \\
\text { of one's name } \\
\text { from non Gusti } \\
\text { into Gusti) }\end{array}$ & $\begin{array}{l}\text { A group of Desa } \\
\text { Pakraman } \\
\text { members used } \\
\text { Gusti title name } \\
\text { Sekelompok where } \\
\text { previously they } \\
\text { used Si title name. }\end{array}$ & $\begin{array}{l}\text { The house yard } \\
\text { was planted with } \\
\text { banana trees by } \\
\text { members of Desa } \\
\text { Pakraman and } 5 \\
\text { families were } \\
\text { evacuated to } \\
\text { Dawan police } \\
\text { station, Klungkung. }\end{array}$ \\
\hline 15. & $\begin{array}{l}1 \quad \text { October } \\
2015\end{array}$ & $\begin{array}{l}\text { Landih, Bangli } \\
\text { (expulsion } \\
\text { implanted by } \\
\text { Desa Pakraman) }\end{array}$ & $\begin{array}{l}\text { Ten heads of family } \\
\text { were accused of } \\
\text { having black magic } \\
\text { (leak) }\end{array}$ & $\begin{array}{l}\text { Ten families } \\
\text { received customary } \\
\text { sanction in the } \\
\text { form of } \\
\text { ostracized from the } \\
\text { Desa Pakraman } \\
\text { (kasepekang) and } \\
\text { cleansing } \\
\text { ceremony } \\
\text { (pengening-ening). }\end{array}$ \\
\hline
\end{tabular}

In addition to the above cases, in fact, many other cases have not yet been presented. The causes of which can be in the form of border disputes, individual conflicts, etc. The number of cases presented on the table indicates that most were in the form of mass anger. In this regard, a columnist in the daily newspaper Bali Post mentions, "Among the various praises addressed to the customary village, praise that says customary village is the last fortress of Bali is often raised... The immediate questions are: whether customary village is the last fortress of Balinese culture? Is not it just the opposite, that it is customary village is the one with the greatest potential to destroy Bali with its various rules?"27

Based on the table, in addition to mass anger cases, there are also kasepekang and manak salah cases as listed in cases number 11 and 12 . In these events, mass anger can be classified as criminal cases that, of course, is not justified by both national law and customary law. Meanwhile, kasepekang and manak salah cases, which are considered the customary case, are actually justified by certain awig-awig of Desa Pakraman. Since these last two cases keep happened time to time, this

27 See Bali Post, February 19, 2003. 
article elaborates whether these two cases are in accordance with international and national human rights principles. Other than kasepekang and manak salah cases, other cases that have not yet surfaced are quite potential to cause social friction at times, e.g. kasulinggihan, which stands for refusal from Desa Pakraman to use Sulinggih (the one who lead Hindu ceremony) from certain soroh (clan), and clancross marriages, which is considered as harassment of the dignity of Balinese women.

The ongoing cases in the practice of daily life indicate that the local awig-awig and dresta still provide room to justify and to tolerate the cases. At the same time, there are resistances to change awig-awig according to the macro-cultural values of Pancasila, religion, and human rights. With such changes, it is expected that Customary Law or awig-awig can be developed in a positive and dynamic direction without losing its universal values. ${ }^{28}$

\section{Kasepekang}

Kasepekang is a social sanction in the form of excommunication from the area of Desa Pakraman, or a prohibition for a member of Desa Pakraman to have social interaction because the person is considered failed to fulfill customary obligations. The prohibition includes the prohibition to be greeted or received information. The violators of this prohibition may be fined. Based on kasepekang sanctions, one needs to be careful in agreeing or disagreeing. Therefore, the cause of this sanction needs to be found out. If it is due to arrogance, exclusivity, or anti-social attitude, therefore, within certain limits, the sanction is still needed to be maintained in the form of training. For instance, the violator must apologize for three times in a row and do community service within a certain period of time, which should not be replaced with other people. Such sanction aims to warning people that as everyone does not play the role as individual human being but also as social human being or customary human being who has social obligations in addition to social rights. However, of course, if the kasepakang sanction is caused by the arrogance of the majority dictator, which is sometimes packaged on behalf of the customary institutions, it is clear that such actions violate the international and national principles and norms of human rights. Considering that the characteristics of kasepekang are mainly an excommunication, the human rights principles and norms that are violated are, among others, Article 19 of the UDHR on the rights of freedom of opinion and expression and to seek and receive information, Article 22 on the rights to social security and free development of personality, as well as Article 27(1) that everyone has the right to freely participate in cultural life of community.

Kesepekang cases also violate Article 1 of ICESCR 1966 on the rights of selfdetermination and rights to pursue economics, social and cultural development freely and Article 15(1) on the rights to take part in cultural life. Furthermore, they also violate Article 1 of ICCPR on the rights of self-determination and rights to pursue economics, social and cultural development freely; Article 17(1) on the rights

28 Soepomo, Bab-bab tentang Hukum Adat, Jakarta: Pradnja Paramita, 1986, p. 20. 
to privacy; Article 22(1) on the rights to freedom of associations with others; and Article 23(1) on the right of family - entitled to protection by society and the state. In national level, Kesepekang contradicts Article 28(C)(91) of the 1945 Constitution (amendment version) that everyone has the right to develop through the fulfillment of basic needs, Article $28 \mathrm{~F}$ that regulates everyone has the right to communicate and to receive information, and Article $28(G)(1)$ that regulates everyone has the right to protection both for himself and his family. Several provisions in the Indonesian Human Rights Law are also violated. They are Article 9(2) that everyone has the right to peace, happiness, and well-being; Article 11 that regulates everyone has the right to grow and to develop in a way that fit; Article 12 that regulates everyone has the right to the protection of personal development; Article 13 that regulates everyone has the right to develop and to receive benefit from art and culture; Article (14)(1) that regulates everyone has the right to communicate and to receive information; Article 25 that regulates everyone has the right to express opinions publicly; Article (29)(1) that everyone has the right to protection both for themselves and their family; Article 30 that everyone has the right to feel safe and secure; and Article 35 that everyone has the right to live in a peaceful, safe, and secure society and nation that fully respects, protects and executes human rights and obligations as set forth in the provisions of the Law.

\section{Manak Salah}

The customary rule on Manak Salah in fact has been abolished by the Decree of the Bali Provincial People's Legislative Council Number 10 of 1951. The consideration of such Decree mentions three reasons of the elimination: (1) the rule is only intended for sudra wangsa (the lowest caste according to Balinese Catur Warna) with an assessment that twins (boy and girl from one pregnancy -hereinafter referred to as kembar buncing) pollute the universe (ngeletehin); (2) isolation for 42 days in the cemetery is considered as violating the feelings of humanity and health; and (3) such action is no longer suitable with the current situation. In relation to the first reason mentioned above, it seems that there has been manipulation of meaning by the authorities at the old time on the term of manak salah. It is because there are some lontars (ancient text written on lontar leaves) that state the "polluting the land" or ngeletehin impact not only occurs due to the birth of kembar buncing in the sudra wangsa but also in the tri wangsa (the other three castes). ${ }^{29}$ As an illustration, there are at least six versions of lontar on manak salah that need to be observed in discussing the rules on manak salah. The first version essentially states that the birth of kembar buncing that occurs in all castes is considered ngeletehin jagad (polluting the universe). If a birth of kembar buncing occurs in the circle of Rsi Catur Patah (Brahmin caste), the punishment is in the form of isolation to a place located under the bale pamiosan and the person in concerned should recite mantras of purification every day. If it happens in the circle of King's family (Ksatria), the punishment is in the form of isolation to a place located under the Bale Agung for

29 M. Kembar Kerepun, Benang Kusut Nama Gelar Gusti di Bali, Denpasar: CV. Bali Media Adhikarsa, 2004, p. 84. 
three months with meditating (tapa samadhi). Meanwhile, if such birth occurs among the circle Waisya (trader family), the punishment is in the form of three months ( 3 times 35 days) of isolation in the great crossroad (Perempatan Agung) and meditating. Furthermore, if the birth of kembar buncing occurs in the circle of Sudra Wangsa (the lowest caste), the babies and their parents will be isolated to the cemetery border for three months. The second version of lontar on manak salah has a very different content to the first version. It states that if the birth of kembar buncing occurs among the circles of Priest or King (Tri Wangsa), it is not considered polluting the universe. On the contrary, if it happens among the Sudra Wangsa circle, it is considered polluting the universe and emulating (amadamada) the King. Therefore, they deserve to be isolated in the great crossroad (Catur Pata or Perempatan Agung) for forty days. The third version is almost entirely the same as the first version, except for the term "Sudra" where the third version uses the term of "Wong Nista". The fourth version is similar with the second version. However, the narrative style between them is different. The fifth version is not much different with the third version. Finally, yet importantly, the sixth version has the same contents and language style with the second version lontar where only a few terms replaced with synonyms. ${ }^{30}$ For the record, the similarity of the six versions of lontar is in every isolation sanction followed by pecaruan (a Balinese Hindu ceremony to maintain harmony between human and nature) sanction.

Considering that manak salah sanction may cause a high risk for baby survival, it can be considered as inhumane and a violation to the human rights principles and norms. Indeed, in reality, children can be considered as one of the vulnerable groups that often become victims of human rights violation. ${ }^{31}$ The Manak Salah is also considered strong violation to the right of health for child or baby. Several human rights principles and norms that are violated upon the manak salah sanction cover, among others, Article 5 of the UDHR that no one shall be subjected to torture or to cruel, inhuman, or degrading treatment or punishment; Article 25 of the UDHR that motherhood and childhood are entitled to special care and assistance (all children, born in or out of wedlock, shall enjoy the same social protection); Article 10 (1) of the ICESCR that the state parties to the covenant recognize that special protection should be accorded to mothers during pregnancy and after childbirth; Article 10 (2) of the ICESCR that special measures of protection and assistance should be taken on behalf of all children; Article 6 (1) of the ICCPR that every human being has the right to life; and Article 24 (1) of ICCPR that every child shall not face any discrimination like race, color, sex, language, religion, national or social origin, property or birth the right.

Manak salah rule also contradicts human Rights Law at the national level. First, it contradicts the 1945 Constitution (after amendment), particularly Article $28 \mathrm{~A}$ that everyone shall have the right to live and to defend his/her life and existence; Article

Ibid., pp. 88-105.

31 Ni Ketut Supasti Dharmawan, Desak Putu Dewi Kasih, I Gede Agus Kurniawan, Putu Aras Samsithawrati, "The Guiding Principles on Business and Human Rights: National Action Plans Toward Corporation Responsibility", Hasanuddin Law Review, Vol. 4, No. 2, 2018, p. 127. 
$28 \mathrm{~B}(1)$ that everyone shall have the right to establish a family and to procreate based upon lawful marriage; Article $28(B)(2)$ that every child shall have the right to live, to grow, and to develop, and the right to protection from violence and discrimination. Based on the Indonesian Human Rights Law, several provisions are also violated. They are, among others, Article 4 on the right to life, the right not to be tortured, etc., which cannot be diminished under any circumstances whatsoever; Article 5(3) that all members of disadvantaged groups in society, such as children, the poor, and the disabled are entitled to greater protection of human rights; Article 9(1) on the right to life for everyone; Article 10(1) that everyone has a right to marry legally, to found a family, and to bear children; Article 52(1) on the right of all children to be protected by parents, family, society, and state; Article 53(1) that every child has the right to life, to maintain life, and to improve living standard; Article 58 that every child has the right to legal protection from all forms of violence, neglect, ill-treatment and so on; Article 62 that every child has the right to access adequate health services and social security as befits physical, emotional, and spiritual needs; Article 66(1) that regulates every child has the right not to be the object of oppression, torture, or inhuman legal punishment; and Article 66(2) that every child has the right not to be deprived of independence.

To minimize the human rights violation, including in matters of trade, there are two approaches. The first is by pushing the international CSO to do the task and the other one is by using internal regulation approach. Government interference can be justified as a part of justice enforcer, ${ }^{32}$ also as a part of government duty bearers.

\section{Conclusion}

The existence of Desa Pakraman is based on the Balinese Local Government Regulation Number 3 of 2003. It is not a fully autonomous community. In addition, it is not an independent entity in both national and international contexts. Therefore, the rules over its members, the awig-awig (as a traditional law instrument) must not deviate from both national and international laws and regulations. Particularly, the ones that are related to human rights values. Although the nature of the traditional law instrument aims to keep the cosmic balance, logically, international and national instruments of human rights need to be references to formulate customary rules, including the awig-awig. The instruments, among others, cover the UDHR 1948, the ICCPR 1966, the ICESCR 1966, the Convention on the Elimination of All Forms of Discrimination against Women 1979, the Convention on the Rights of the Child 1990, the 1945 Constitution (amendment version), and the Indonesian Human Rights Law. Nowadays, violence (mass anger) to resolving customary issues often occurs due to the lack of understanding on human rights. Fundamentally, there are obligations recognized by national and international legal instruments on human rights. The cases in Bali potentially cause social friction due to their violation

32 Birkah Latif, SM Noor, Juajir Suardi, Irwansyah, "Human Rights Protection in Trade: A Challenge", Padjadjaran Jurnal Ilmu Hukum, Vol. 5, No. 2, 2018, p. 384. 
on human rights values, particularly that is related to an adequate living standard, like kasepekang and manak salah.

\section{References}

\section{Books}

Boer Mauna, Hukum Internasional, Pengertian, Peranan dan Fungsi dalam Era Dinamika Global, $2^{\text {nd }}$ Edition, Alumni, Bandung, 2011.

Chowdhury (et.al.), An Introduction to International Human Rights Law, Koninklijke Brill, Leiden, 2010.

Ghandhi, Sandy, Blackstone's International Human Rights Documents, $6^{\text {th }}$ Edition, Oxford University Press, New York, 2008.

Hans Kelsen, General Theory of Norm, Clarendon Press, Oxford, 1991.

Jimly Asshidiqie, Komentar atas Pasal-pasal Undang-undang Dasar Negara Republik Indonesia Tahun 1945, Sinar Grafika, Jakarta, 2010.

Jimly Asshidiqie, Perihal Undang-undang, Konstitusi Press, Jakarta, 2016.

M. Kembar Kerepun, Benang Kusut Nama Gelar Gusti di Bali, Bali Media Adhikarsa, Denpasar, 2004.

Maria Farida Indrati Soeprapto, IImu Perundang-undangan 1, Jenis, Fungsi dan Materi Muatan, Kanisius, Yogyakarta, 2007.

Romli Atmasasmita, Reformasi Hukum, Hak Asasi Manusia, dan Penegakan Hukum, Mandar Maju, Bandung, 2001.

Soepomo, Bab-bab tentang Hukum Adat, Pradnja Paramita, Jakarta, 1986

Tomuschat, Christian, Human Rights between Idealism and Realism, $2^{\text {nd }}$ Edition, Oxford University Press, New York, 2008.

\section{Other Documents}

Arjawa, I. B. S., \& Jayantiari, I. M. R., "Democratic values in Balinese traditional society: Analysis of the making and the content of Desa Pakraman's awigawig", Masyarakat, Kebudayaan dan Politik, Vol. 30, No. 4, 2017.

Bali Post Daily Newspaper.

Birkah Latif, SM Noor, Juajir Suardi, Irwansyah, "Human Rights Protection in Trade: A Challenge", Padjadjaran Jurnal Ilmu Hukum, Vol. 5, No. 2, 2018.

DenPost Daily Newspaper.

H.C. Ndun, S. Suttor, and I.G.A.A.D. Widhiyaastuti, "Does Customary Law Discriminate Balinese Women's Inheritance Rights?", Udayana Journal of Law and Culture, Vol. 2, No. 1, 2018.

I.K. Sudantra, "Pengaturan Penduduk Pendatang dalam Awig-Awig Desa Pakraman" PIRAMIDA, 2000.

Kuwali, D., "Battle for Sex: Protecting Sexual (ity) Rights in Africa", Human Rights Quarterly, Vol. 36, 2014.

N.K. Setyawati, "Kedudukan perempuan Hindu menurut hukum waris adat Bali dalam perspektif kesetaraan gender", Jurnal Penelitian Agama Hindu, Vol. 1, No. $2,2017$. 
Ni Ketut Supasti Dharmawan, Desak Putu Dewi Kasih, I Gede Agus Kurniawan, Putu Aras Samsithawrati, "The Guiding Principles on Business and Human Rights: National Action Plans Toward Corporation Responsibility", Hasanuddin Law Review, Vol. 4, No. 2, 2018.

Philips, J., "On setting priorities among human rights", Human Rights Review, Vol. 15, No. 3, 2014.

Simmons, B., "Civil Rights in International Law: Compliance with Aspects of the "International Bill of Rights", Indiana Journal of Global Legal Studies, Vol. 16, No. 2, 2009.

W.G. Suacana, "Budaya demokrasi dalam kehidupan masyarakat desa di Bali", Journal of Bali Studies, Vol. 1, No. 1, 2011.

Westendorp, I., "Personal Status Law and Women's Right to Equality in Law and in Practice: The Case of Land Rights of Balinese Hindu Women", Journal of Human Rights Practice, Vol. 7, No. 3, 2015.

\section{Legal Documents}

The 1945 Constitution of the Republic of Indonesia.

Bali Local Regulation Number 3 of 2003 on Desa Pakraman [Peraturan Daerah Provinsi Bali Nomor 3 Tahun 2003 tentang Desa Pakraman].

General Elucidation of Law Number 39 of 1999 on Human Rights [Penjelasan Umum atas Undang-Undang Nomor 39 Tahun 1999 tentang Hak Asasi Manusia].

General Elucidation of Law Number 19 of 2011 on the Ratification of Convention on the Rights of Persons with Disabilities [Penjelasan Umum atas Undang-Undang Nomor 19 Tahun 2011 tentang Pengesahan Konvensi Mengenai Hak-Hak Penyandang Disabilitas].

Universal Declaration of Human Rights 1948.

International Covenant on Civil and Political Rights 1966.

International Covenant on Economic, Social, and Cultural Rights 1966. 